\title{
Membaharui Dunia Lewat Semangat Persaudaraan Global
}

\author{
Hendro Setiawan \\ Sekolah Tinggi Teologi Sriwijaya \\ Hdrsetiawan@yahoo.co.id
}

\begin{abstract}
Pope Francis' newest encyclical, entitled "On The Fraternity and Social Friendship" (Fratelli Tutti) was signed on October 3, 2020. This encyclical emerged as the world was struggling against the Covid 19 pandemic. This encyclical is considered a universal proposal and is proposed to improve the world. Global phenomena in the form of: social injustice, environmental damage, ineffective handling of the pandemic, and various other major problems, considered the Pope as urgent to be reflected and renewed. Through this encyclical, the pope invites all parties, all religions, even atheists, to work together in creating a better world for everyone. Since the beginning of the pandemic, Pope Francis has reflected on the pandemic as a universal call to strengthen human brotherhood. The Pope invited all parties during the pandemic, to think about and prepare for a better world in the context of humanity. The world after a pandemic must be a world that is more welcoming to everyone without exception. It is hoped that a world that is more humane and in solidarity will be able to overcome previous human problems. The encyclical "On The Fraternity and Social Friendship" (Fratelli Tutti) is a concrete form of the pope's thinking on what is needed to reform the world today. The research contained in this paper is aimed at proving the relevance of this encyclical. The method used is literature study by dissecting the contents of the encyclical and comparing it with other relevant and relevant thoughts. This research proves that the encyclical "On The Fraternity and Social Friendship" (Fratelli Tutti) is a relevant proposal and worthy of attention in efforts to improve the world today.
\end{abstract}

Keywords: Social friendship, solidarity, humanity, global fraternity.

Abstrak: Ensiklik Paus Fransiskus terbaru, yang berjudul "Persaudaraan dan Persahabatan Sosial" (Fratelli Tutti) telah ditandatangani pada tanggal 3 Oktober 2020. Ensiklik ini muncul ketika dunia tengah berjuang melawan pandemi Covid 19. Ensiklik ini dianggap sebagai sebuah proposal universal dan diajukan untuk memperbaiki dunia. Fenomena global berupa: ketidak-adilan sosial, kerusakan lingkungan, ketidak-efektifan penanganan pandemi, dan berbagai permasalahan besar lainnya, dinilai Paus sebagai hal mendesak untuk direfleksikan dian dibaharui. Melalui ensiklik ini, paus mengajak semua pihak, semua agama, bahkan para ateis, untuk bekerjasama dalam menciptakan dunia yang lebih baik untuk semua orang. Sejak awal terjadinya pandemi, Paus Fransiskus telah merefleksikan pandemi sebagai sebagai panggilan universal untuk mempererat persaudaraan manusia. Paus mengajak semua pihak selama pandemi, untuk memikirkan dan mempersiapkan dunia yang lebih baik dalam konteks kemanusiaan. Dunia setelah pandemi harus menjadi dunia yang lebih ramah untuk semua orang tanpa kecuali. Dunia yang lebih manusiawi dan bersolidaritas, diharapkan mampu mengatasi masalah-masalah kemanusiaan masa sebelumnya. Ensiklik "Persaudaraan dan Persahabatan Sosial" (Fratelli TuttI) adalah bentuk konkrit pemikiran paus tentang apa yang dibutuhkan untuk membaharui dunia saat ini. Penelitian yang tertuang dalam tulisan ini ditujukan untuk membuktikan relevansi ensiklik itu. Metode yang digunakan adalah studi kepustakaan dengan membedah isi ensiklik dan membandingkannya dengan pemikiran-pemikiran lain yang terkait dan relevan. Penelitian ini berupaya membuktikan bahwa ensiklik "Persaudaraan dan Persahabatan Sosial" (Fratelli Tutti) merupakan proposal yang relevan dan layak diperhatikan dalam upaya memperbaiki dunia masa ini.

Kata Kunci: Persahabatan sosial, solidaritas, kemanusiaan, persaudaraan global.

Article History

\begin{tabular}{|l|l|l|}
\hline Submitted: 31 Oktober 2020 & Revised: 2 Desember 2020 & Accepted: 31 Desember 2020 \\
\hline
\end{tabular}




\section{PENDAHULUAN}

Ada banyak permasalahan dalam dunia yang sedang dihadapi umat manusia saat ini. Ancaman kerusakan lingkungan merupakan kenyataan yang terus memburuk. Suhu bumi terus meningkat, es dikutub mulai mencair, habitat terdegradasi, flora dan fauna liar makin banyak yang punah (Harari, 2018). Emisi gas rumah kaca telah menjelma menjadi ancaman serius bagi dunia. Masalah lain adalah ketidakadilan atau kesenjangan sosial yang kian hari kian parah. Sekitar 850 juta orang saat ini sedang menderita kelaparan diseluruh dunia. 6 juta anak meninggal karena kelaparan setiap tahun diseluruh dunia. Ini terjadi ditengah masyarakat moderen yang cenderung hidup dengan tingkat konsumsi berlebihan. Kenyataan lebarnya jurang kesenjangan sosial di dunia adalah hal yang menyedihkan Beberapa orang di dunia saat ini hidup dengan kekayaan berlebihan, sementara ditempat lain banyak orang kelaparan. Saat ini 1 persen orang terkaya di dunia memiliki 50\% kekayaan dunia (Harari, 2018). Ratusan orang terkaya secara bersama, memiliki kekayaan lebih dari 4 milyar orang yang paling miskin (Harari, 2018). Masa ini telah menciptakan masyarakat yang paling tidak setara sepanjang sejarah manusia (Harari, 2018).

Berbagai permasalahan kejiwaan juga muncul pada masa ini, lebih dari masamasa sebelumnya. Penelitian yang dlakukan oleh filsuf moral Peter Singer di Amerika telah menunjukkan peningkatan tajam kebutuhan psikoterapi (konseling psikologi) pada masyarakat Amerika. Banyak diantaranya sampai butuh pertemuan beberapa kali dalam seminggu. Singer menunjukkan fenomena banyak orang Amerika yang menghabiskan seperempat dari penghasilannya untuk membayar psikolog, dan masalah utama yang dihadapi mereka adalah "ketidak-bermaknaan hidup" (Singer, 1993). Kesehatan mental yang buruk terindikasi pada munculnya gejala anomie (hidup tanpa makna, tanpa tujuan, jatuh dalam rutinitas yang tak bermakna) dan gejala alienasi (merasa kesepian, tersingkirkan, tidak berguna). Kedua gejala ini justru banyak muncul dalam kehidupan manusia dewasa ini. Harian Kompas tanggal 12 Juli 2013 mengulas tentang data WHO tahun 2012 yang menunjukkan bahwa sekitar satu juta orang tewas akibat bunuh diri diseluruh dunia setiap tahun. Dan sekitar sepuluh sampai dua puluh kali lipat dari angka itu, merupakan angka percobaan bunuh diri. Angka ini jauh lebih besar daripada penggabungan korban tewas akibat perang dan pembunuhan. Fenomena semacam ini belum pernah terjadi pada masa-masa sebelumnya.

Post modernisme telah membentuk masyarakat yang paling apatis sepanjang sejarah. Masyarakat yang tidak tahu lagi harus bagaimana untuk mengatasi 
permasalahannya. Masalah lingkungan misalnya, hingga saat ini belum ada upaya nyata yang memadai untuk menghentikannya Beberapa KTT antar negara tingkat global telah diadakan, namun menghasilkan komitmen memadai untuk mengurangi emisi karbon di setiap negara. Banyak visi mengatasi ini, tetapi semua masih hanya sebatas wacana belaka (Setiawan, 2014). Tidak ada kepastian kapan bencana lingkungan dapat ditanggulangi. Demikian juga masalah ketidakadilan, berkurangnya pekerjaan akibat teknologi, dll, seakan terus menguat tanpa ada solusi yang jelas.

Dunia masa ini juga seakan dunia yang tanpa kepemimpinan (Harari, 2015). Permasalahan utama politik dunia pada masa ini adalah: ketiadaan kekuatan yang mampu mengontrol, dan tidak ada lagi negara besar yang memimpin. Semua negara cenderung sibuk berfokus pada kepentingannya sendiri, dan mengabaikan permasalahan global. Politik berkembang tanpa kontrol publik yang memadai. Masyarakat luas seakan hanya punya kesempatan mengontrol pada saat pemilu limatahunan. Bentuk kontrol yang lima-tahunan itupun tidak berjalan semestinya, mengingat kekuatan-kekuatan politik telah memanipulasi dan mengontrol opini masyarakat lewat media sosial selama proses pemilu. Terungkapnya skandal "Cambridge Analitica" tahun 2017 telah menunjukan "puncak gunung es" fenomena ini. Facebook telah digunakan untuk mengontrol pemilu banyak negara diseluruh dunia (Harari, 2018). Situasi ini menunjukkan bahwa dalam situasi pemilu pun, kekuatan segelintir elitlah yang mengendalikan warga negara, bukan seperti yang seharusnya. Kedaulatan rakyat yang seharusnya mengontrol politik, justru telah dikendalikan lewat media sosial.

Politik masa ini telah berkembang sangat kompleks, jauh diluar jangkauan pemahaman pemilih (Nichols, 2017). Pro dan kontra mewarnai setiap kebijakan. Ruang debat publik, menjadi ruang yang sangat bising dan sulit dipahami masyarakat luas (Nichols, 2017). Buzzer (pendengung) pemerintah dan anti pemerintah berlomba mengisi pikiran masyarakat. Masyarakat dibanjiri informasi yang membingungkan setiap saat, tanpa tahu kebenarannya atau cara memilahnya. Politik berjalan terus dengan cara itu sampai pada pemilu berikutnya. Masyarakat tidak tahu apa yang ada dibalik proses politik, konspirasi apa yang terjadi, kolusi, nepotisme apa yang mewarnai (Nichols, 2017). Tetapi masyarakatlah yang harus menghadapi kenyataan dampak buruk politik yang tidak terkontrol berupa kesenjangan sosial, dst. Yang dekat dengan lingkaran kekuasaan politik menjadi semakin kaya, dan sebaliknya, masyarakat miskin yang seharusnya dilindungi justru makin miskin dan menderita. 
Konspirasi politik masa ini bukan hanya terjadi pada tingkat internal negara, tetapi pada tingkat global. Perusahaan-perusahaan dan pemain-pemain global bahkan punya kekuasaan yang tidak kelihatan, untuk menggerakkan para pemimpin dunia. Mereka punya jaringan dan kekuasaan lintas negara, dan punya cara-cara untuk mendikte atau bahkan menggulingkan kekuasaan politik suatu negara yang tidak mau patuh. Sistem kapitalisme membuat hampir tidak ada negara yang berdaulat penuh atas ekonominya sendiri. Absennya kepemimpinan dunia membuat nilai-nilai etika dan moral lumpuh. Seakan dunia kembali pada hukum rimba, siapa yang kuat dia berkuasa. Masa depan menjadi kabur, tidak dapat lagi diprediksi (Harari, 2011).

Penanganan pandemi yang tidak efektif di banyak negara, bahkan negaranegara besar dan adikuasa, ikut memperburuk situasi. Seakan manusia pada masa ini tidak mampu belajar dari sejarah wabah yang sudah berkali terjadi di masa lalu. Sikap yang mencerminkan kebodohan dan keras kepala terus dipertunjukkan di sanasini dalam mengatasi wabah. Filsuf psikoanalitik Slovenia, Slavoj Zizek, menunjukkan bahwa pandemi Covid 19 seharusnya tidak hanya diatasi dengan isolasi wilayah atau negara. Diperlukan koordinasi dan kolaborasi global untuk dapat menangani pandemi secara efektif (Maqin, 2020). Sayangnya dunia justru kekurangan semangat itu. Egoisme sektoral justru menghalangi solidaritas. Akibatnya marak penanganan yang tidak efektif dan banyak korban yang tidak perlu. Zizek, menganggap bawa pandemi Covid 19 menghadirkan panggilan bagi umat manusia untuk memperkuat hubungan antara manusia (Zizek, 2020).

Ditengah gambaran negatif arah pertumbuhan dunia saat ini, sebuah proposal pembaharuan dunia adalah suatu yang menarik, penting, dan memberi harapan. Apalagi diajukan oleh seorang pemimpin agama besar di dunia. Karena itu, membahas proposal ini secara ilmiah sangat layak dilakukan. Metode yang digunakan dalam penelitian ini adalah studi atas ensiklik yang menjadi proposal pembaharuan dunia itu sendiri dan membandingkan dengan tulisan ilmiah dari tokoh lain yang relevan. Bagaimana ensiklik ini merumuskan akar masalah dunia masa ini? Relevankah? Apa tesisnya? Apa dasar ajaran agama dari tesis itu? Apakah tesis itu mampu menyelesaikan akar masalah yang telah dirumuskan sebelumnya? Bagaimana tesis itu dapat diwujudkan dalam kehidupan masyarakat masa ini? Apakah dapat diterima semua pihak dalam masyarakat yang beragam? Melalui pembahasan-pembahasan itu ditarik kesimpulan atas relevansi proposal bagi pembaharuan dunia masa ini. 


\section{METODE PENELITIAN}

Penelitian ini merupakan penelitian kualitatif dengan menggunakan metode deskriptif-analitis. Metode deskriptif merupakan upaya untuk menguraikan objek kajian dimana data yang tersedia dianalisis untuk membuat evaluasi kritis atasnya.

\section{HASIL DAN PEMBAHASAN \\ Permasalahan Dunia Yang Tertutup}

Ini tema bab 1 ensiklik. Fenomena-fenomena kehidupan sehari-hari, yang nyata tak terbantahkan, ketika ditelusuri dengan teliti dapat mengarahkan pada akar masalah. Fenomena nyata adalah jejak dari akar masalah. Pada bagian pertama ensiklik "Persaudaraan dan Persahabatan Sosial" (Fratelli Tutti), Paus Fransiskus menunjukkan fenomena-fenomena itu dan menelusuri akar permasalahan dunia saat ini. Paus memulai analisanya berangkat dari fenomena kecenderungan kuat dunia masa ini untuk: "menolak pengembangan persaudaraan universal" (Francis, 2020).

Pendapat paus ini senada dengan pemikiran filsuf psikoanalitik Slovenia, Slavoj Zizek, melihat bahwa penanganan pandemi Covid 19 menunjukkan kurangnya persaudaraan universal. Karena itu, Zizek mengangkat perlunya menghadirkan kembali panggilan umat manusia untuk memperkuat hubungan antara manusia (Zizek, 2020). Zizek menunjukkan bahwa diperlukan koordinasi dan kolaborasi global untuk dapat menangani pandemi secara efektif (Zizek, 2020). Sayangnya dunia justru didominasi egoisme sektoral yang menghalangi solidaritas. Akibatnya marak penanganan yang tidak efektif dan banyak korban yang tidak perlu. Dunia membutuhkan gerak menuju masyarakat yang terkoordinasi secara sukarela. Krisis akibat pandemi Covid 19 menunjukkan kebutuhan akan solidaritas dan kerjasama global diseluruh dunia, untuk dapat bertahan bersama (Zizek, 2020). Senada dengan Zizek, sejarawan Israel, Yuval Noah Harari, menyatakan bahwa pandemi tidak bisa diatasi hanya dengan isolasi wilayah. Pandemi harus diatasi lewat tingkat kepercayaan dan kerjasama internasional yang tinggi (Harari, 2018). Harari menunjukkan bahwa permasalahan utama penanganan pandemi saat ini adalah tidak adanya kepemimpinan global yang dipercaya dan mampu menyatukan langkah (Harari, 2018). Pemimpin dengan prinsip "me first", jelas tidak memadai (Harari, 2018).

Paus menunjukkan bawa pada masa ini, ditengah masih bergaungnya harapan penyatuan negara-negara Uni Eropa dan Amerika Latin, justru muncul kecenderungan kuat berkembangnya bentuk nasionalisme yang sempit, ekstrim, dan agresif (Francis, 2020). Fenomena ini ditandai dengan menguatnya egoisme dan 
makin hilangnya rasa keterikatan sosial di seluruh dunia. Globalisasi diwujudkan dalam keterbukaan sistem ekonomi semata, yang menyatukan arus ekonomi dunia (Francis, 2020). Tetapi globalisasi ternyata tidak menyatukan dimensi-dimensi hidup yang lain. Globalisasi berhasil membuat mata uang asing diterima dengan mudah dimana-mana, tetapi orang asing atau yang berbeda tidak mudah diterima sebagai saudara. Keterbukaan ekonomi global membuat kekuatan ekonomi menjadi kekuatan besar yang mampu mendominasi politik dan aspek hidup lainnya. Akibatnya, timbul bentuk baru kolonisasi terselubung atas nama globalisasi. Kolonisasi ini merenggut kedaulatan ekonomi dan politik suatu negara. Kolonisasi yang berupaya menyeragamkan, juga membawa konsekwensi pengabaian tradisi lokal, apatisme masyarakat, dan hilangnya identitas spiritual. Orang muda tercerabut dari akar sejarahnya. Paus menyebut ini dengan fenomena "dekonstruksi” (Francis, 2020).

Apa yang dikemukakan paus ini pernah disampaikan oleh David de Cravalho, seorang peneliti dampak globalisasi. Cravalho menyatakan: "tidak ada tempat lagi untuk solidaritas dalam pasar bebas, hubungan antar manusia terreduksi menjadi hanya pada level transaksi dagang antara penjual dan pembeli. Transaksi menjadi modus utama sistem pasar bebas yang berfokus hanya pada kepentingan individu, bukan pada kelompok sosial yang lebih luas atau yang dirugikan"(Society, 2000).

Kepentingan ekonomi yang makin kuat, mampu mengendalikan politik. Politik mendominasi dan mengontrol masyarakat dengan cara menyebar keputusasaan dan ketakutan, ini terjadi dibanyak negara (Francis, 2020). Media sosial menjadi alat politik yang handal untuk tujuan ini. Dalam budaya kompetisi yang hanya memperjuangkan kepentingan diri, kemenangan dicapai dengan menghancurkan musuh. Fokus ekonomi yang mengejar keuntungan cepat, punya konsekwensi mengabaikan nilainilai, menghancurkan alam dan persaudaraan antar manusia (Francis, 2020). Akibatnya, banyak orang tersingkirkan, termasuk diantaranya para lansia dan orangorang miskin. Mereka dianggap "tidak berguna" dan "tidak lagi dibutuhkan" (Francis, 2020). Ini terjadi ditengah budaya modern yang mudah membuang segala sesuatu yang dianggap tidak diperlukan lagi (thrown away culture). Banyak lansia yang harus menjalani masa tua secara menyedihkan dan kesepian. Ini juga berdampak pada orang-orang muda yang kehilangan hubungan dengan "akar" keluarga dan kebijaksanaan orang tua (Francis, 2020).

Ini juga senada dengan apa yang dinyatakan penelitian Madya Utama dan Matheus Purwatma, bahwa: sistem ekonomi global yang ditandai dengan kompetisi sengit, budaya boros dan "membuang apa saja" (thrown away) mengakibatkan orang- 
orang miskin dan lansia tersingkir dari masyarakat. Bahkan seakan-akan mereka benar-benar tidak lagi menjadi bagian dalam masyarakat. Mereka adalah orang-orang yang terbuang, "the leftovers" (SJ. \& Pr., 2015).

Keserakahan ekonomi juga berdampak pada upaya-upaya efisiensi menurunkan upah buruh, penggunaan teknologi masif dengan dampak PHK. Akibatnya muncul bentuk-bentuk baru kemiskinan yang mengeliminasi manusia dari kesempatan nyata ambil bagian dalam sejarah (Francis, 2020). Nyata bahwa pelaksanaan Hak Asasi Manusia (HAM) masih tidak setara untuk semua manusia (Francis, 2020). Martabat wanita belum mendapat pengakuan selayaknya di banyak tempat. Masih banyak wanita diperlakukan sebagai budak dan obyek dalam berbagai bentuk (Francis, 2020). Perang, terorisme, persekusi agama atau rasial, dan segala sesuatu yang mengancam martabat manusia, disikapi dengan standar ganda, sesuai keinginan kekuasaan ekonomi belaka (Francis, 2020). Setiap kekerasan adalah bentuk: "ketidak-mampuan memenuhi panggilan alamiah akan persaudaraan" (Francis, 2020).

Manusia modern hanya peduli pada keamanan dan kenyamanan pribadinya belaka. Padahal mengejar rasa aman dan nyaman berdasarkan mentalitas ketakutan dan ketidakpercayaan adalah sesat. Marak budaya membangun "tembok" untuk segala hal, tembok di hati, di tanah, dll. Ini dilakukan untuk melindungi diri dari segala "yang berbeda". Ini terjadi akibat mereka kurang mampu membangun relasi dengan "yang berbeda" (Francis, 2020). hal ini memicu perasaan kesepian, ketakutan, dan tidak aman, dialami banyak orang pada masa ini. Melemahnya tanggungjawab dan nilai-nilai spiritual, berujung pada perasaan depresi, isolasi dan frustasi (Francis, 2020).

Kritik atas budaya modern yang tertutup juga pernah dikemukakan oleh filsuf terkenal Yahudi, Emmanuel Levinas (1912-1995). Lewat bukunya yang berjudul "Totalitas dan Yang Tak Terhingga" (Totalite et Infini), Levinas mengkritik pemikiran barat yang mengejar totalitas. Totalitas yang dimaksud disini adalah keseluruhan yang berpangkal pada "ego" sebagai pusatnya. Pemikiran tertutup yang bertolak dari "aku" dan kembali pada "aku". Totalitas itu ingin didobrak oleh Levinas dengan kesadaran akan keberadaan "Yang tak Terhingga" pada orang lain. Totalitas itu pecah pada perjumpaan dengan orang lain (Bertens, 2001). Menurut Levinas, begitu ada orang menyapa kita, terjadilah pewahyuan. Levinas menyebut peristiwa ini dengan istilah "epiphania" (Suseno, 2004), atau penampakan diri yang Illahi. Dalam "muka" tampak "Yang Tak Terhingga". 
Nyatanya, globalisasi telah berjalan tanpa arah jelas. Rasa kepemilikan bersama dunia sebagai satu keluarga makin kabur. Masyarakat global makin lupa bahwa sedang berada dalam satu kapal yang sama. Manusia diisolasi oleh kepentingan dirinya sendiri (Francis, 2020). Pendapat yang senada soal globalisasi yang tanpa arah juga dikemukakan sejarawan Israel, Yuval Noah Harari (Harari, 2015). Perlombaan kesejahteraan pribadi telah menghasilkan kesenjangan yang parah. Pertumbuhan ilmu pengetahuan dan teknologi juga nampak telah mengabaikan tujuan kebaikan bersama. Dunia menjadi semakin tidak adil.

Migrasi menjadi fenomena penting pada zaman ini. Migrasi menjadi fenomena yang nyata atas berkurangnya tanggungjawab sosial di dunia masa ini (Francis, 2020). Para migran adalah korban yang seakan telah kehilangan martabatnya sebagai manusia. Mereka menderita, ditolak dimana-mana, banyak diantaranya yang diesploitasi kartel obat bius, menjadi korban perdagangan manusia, mengalami kekerasan, dll. Para migran sering kali juga dijadikan alat politik. Ketakutan berhadapan dengan yang asing, terimplikasi pada perlakuan buruk terhadap para migran (Francis, 2020). Ketika budaya tertutup dan intoleran terhadap yang asing menguat, maka kebutuhan privasi juga meningkat. Kebenaran hanya didasarkan atas sudut pandang sendiri. Budaya xenophobia (tidak suka terhadap yang berbeda) menguat. Akibatnya individualisme menguat dan persahabatan menurun. Rasa hormat terhadap orang lain menurun (Francis, 2020).

Akibat terjebak dalam kenyamanan konsumerisme, manusia cenderung terisolasi dan mudah mengorbankan yang lain (Francis, 2020). Pendapat ini juga dikemukakan filsuf Adelbert Snijder. Snijder dalam bukunya yang berjudul Manusia: Paradoks dan Seruan, juga menyatakan bahwa pusat manusia justru ada di luar dirinya. Manusia adalah mahluk yang terarah keluar. Manusia menemukan dirinya di dunia dan terarah pada sesama. Dalam pertemuan dengan sesama, aku menjadi aku. Sesamaku hadir dalam segala kegiatanku. Tidak ada aku tanpa dunia dan tidak ada aku tanpa sesama (Sinjders, 20014).

Kepentingan ekonomi besar dibalik dunia digital, telah memanipulasi kesadaran manusia dan demokrasi (Francis, 2020). Media sosial merekam semua prilaku individu. Semua seakan "telanjang" dan dibawah pengawasan media sosial. Dunia digital juga berperan dalam peningkatan bentuk-bentuk destruktif fanatisme agama yang suka menjelek-jelekkan yang berbeda (Francis, 2020). Standar etika untuk menghormati yang berbeda cenderung diabaikan. Banjir informasi yang disediakan 
internet seringkali tidak menghasilkan kebijaksanaan, tetapi sebaliknya, membangkitkan ilusi.

Kebijaksanaan yang sejati seharusnya selalu sejalan dengan realitas, tetapi lingkaran virtual cenderung mengisolasi manusia dari dunia nyata (Francis, 2020). Isolasi virtual menyebabkan kemampuan manusia mendengarkan yang lain berkurang. Dunia masa ini adalah dunia yang tuli, terutama terhadap orang-orang miskin dan terbuang. Apa yang dikemukakan paus sesuai dengan hasil penelitian Ben Aggger, seorang guru besar sosiologi Universitas Texas, USA. Aggger menunjukkan pengaruh besar kemajuan teknologi informasi dan hiburan terhadap pemahaman identitas masyarakat modern. Aggger menunjukkan bahwa produk teknologi modern seperti internet nyatanya "justru dapat menjadi alat untuk menjebak atau membebaskan manusia" (Agger, 2004). Yuval Noah Harari juga menyatakan kecenderungan manusia masa ini yang diperbudak oleh data internet (Harari, 2018). Padahal tokoh perdamaian dan orang suci Fransiskus dari Assisi mengajarkan untuk mendengarkan suara Tuhan lewat suara orang-orang miskin. Ini semua memicu cara hidup masa ini, yang berfokus hanya pada kepentingan diri, menjadi tak terkendali (Francis, 2020).

Dominasi ekonomi global lewat globalisasi, mendorong negara miskin untuk meniru budaya negara kaya. Globalisasi punya kecenderungan menyeragamkan segala sesuatu mengacu pada budaya negara kaya. Akibatnya nilai-nilai tradisi dan kearifan lokal di banyak negara miskin ditinggalkan. Dengan memutus rantai tradisi, maka sebuah bangsa akan kehilangan identitas dan harga diri sejatinya. Akibatnya, kini banyak orang hidup dengan perasaan teralienasi (terasing), kehilangan jati diri, dan tidak berakar. Hancurnya harga diri suatu bangsa, memudahkan elit untuk mendominasinya lewat sarana media sosial. Dominasi dilakukan demi pencapaian kepentingan sempit mereka.(Francis, 2020) Krisis identitas memudahkan seseorang untuk dimanipulasi. Oleh karena semua itu, dunia masa ini adalah dunia yang diselimuti awan gelap dan membutuhkan harapan baru akan pembaharuan. Yuval Noah Harari juga menyampaikan fenomena masa kini berupa globalisasi tanpa citacita global bersama, selain kepentingan sempit (Harari, 2018).

\section{Dasar Ajaran}

Ensiklik ini ditulis berdasarkan inspirasi sejarah pertemuan orang suci Katolik St. Fransiskus dari Assisi dengan Sultan Malik-El-Kamil ditengah situasi perang salib delapan abad lalu (Francis, 2020). Oleh karenanya, ensiklik ini ditandatangani di dekat 
makam St. Fransiskus di kota Assisi, Italia. Pertemuan bersejarah St. Fransiskus dari Assisi dan Sultan Malik-El-Kamil berlangsung di Mesir tahun 1219. Pertemuan kedua tokoh karismatik dari dua agama yang sedang berperang, berlangsung damai, hangat, dan penuh persaudaraan. Keduanya mampu berdialog dengan terbuka dan saling menghormati satu sama lain. Lewat pertemuan itu mereka juga belajar satu sama lain. Sejarah menghormati pertemuan besar ini. Beberapa pertemuan besar tentang perdamaian antar agama, telah diadakan di Assisi untuk mengenang peristiwa bersejarah ini.

Sebelum ensiklik ini, Paus Fransiskus juga menemui Imam Besar Ahmad AlThayeb pada 4 Februari 2019 di Abu Dhabi. Pertemuan ini sekaligus mengenang 800 tahun pertemuan St. Fransiskus dari Assisi dengan Sultan Malik-El-Kamil. Dalam pertemuan ini mereka berdua menandatandatangani "Dokumen Persaudaraan Manusia untuk Perdamaian Dunia dan Hidup Berdampingan”, yang kemudian sering disebut dengan Deklarasi Abu Dhabi. Dokumen ini utamanya mendorong hubungan yang lebih erat antar umat beragama dan mempromosikan umat beragama untuk dapat hidup berdampingan secara damai, sembari menangkal dampak negatif radikalisme atas nama agama. Kedua peristiwa bersejarah dalam hubungan antar agama tahun 1219 dan 2019 inilah yang melatar belakangi pemikiran yang dikandung ensiklik "Persaudaraan dan Persahabatan Sosial" (Fratelli Tutti).

Pemikiran Paus dalam ensiklik "Persaudaraan dan Persahabatan Sosial" (Fratelli Tutti), utamanya didasarkan oleh perikop Injil: "Orang Samaria yang baik hati" (Luk 10: 25-37). Kisah ini menjelaskan ajaran Yesus tentang bagaimana harus mengasihi sesama. Dalam kisah itu, orang dalam kesusahan yang dianggap mengganggu kenyamanan, karena itu dihindari. Fenomena ini adalah tanda masyarakat tidak sehat (Francis, 2020). Ditengah situasi yang tidak sehat itu, hadir orang Samaria yang membangun ikatan sosial dengan menolong orang yang mengalami kesusahan itu. Lewat perikop ini, Paus menunjukkan permasalahan dan cara menyembuhkan dunia masa ini. Keluhuran martabat manusia terletak pada upayanya untuk keluar dari isolasi kenyamanan, dan berani ambil bagian dalam penderitaan sesama, seperti orang Samaria dalam kisah itu (Francis, 2020).

Kisah orang Samaria yang baik hati, sangat relevan dengan situasi dunia masa ini. Imam dan Levi dalam cerita itu menunjukkan bahwa percaya dan memuja Allah saja tidaklah cukup (Francis, 2020). Iman juga menuntut tindakan nyata. Fokus pada keamanan, kenyamanan diri, dan menghindari yang berbeda, membuat mereka berdua melewati saja orang yang membutuhkan itu. Inilah yang membuat hukum kasih 
pada sesama gagal. Perampok dalam kisah itu, dapat bertindak leluasa dalam masyarakat yang dimanipulasi kepentingan diri. Korban, selain terluka, juga ditinggalkan sendirian dalam masyarakat yang tidak berdaya. Masyarakat yang tidak sehat membiarkannya sendirian dalam kerapuhan. Orang Samaria yang baik hati menunjukkan panggilan untuk bertanggungjawab atas situasi konkrit. Inilah perintah Yesus tentang tugas perutusan terhadap sesama yang merubah hidup. Orang yang mengambil tanggungjawab seperti orang Samaria itu, tidak menyediakan ruang dalam hatinya untuk manipulasi ideologis bentuk apapun (Francis, 2020).

Paus juga menunjukkan bahwa Kitab Suci penuh dengan ajaran tentang hubungan antar manusia yang benar. Kisah Kain yang menolak bertanggungjawab atas adiknya, Abel (Kej 4:9). Ayub 31:15 menyatakan: "bukankah la, yang membuat aku dalam kandungan, membuat orang itu juga? Bukankah satu juga yang membentuk kami dalam rahim?". St Irenaeus menyatakan: "seseorang pencari kebenaran seharusnya tidak berfokus pada perbedaan antar manusia........." (Francis, 2020). Jemaat perdana yang hidup sebagai minoritas yang terisolasi ditengah para penyembah berhala, tetap memegang teguh sikap mengasihi sesama. Dalam Mat 25: 35 , Yesus bahkan mengidentikkan dirinya dengan "orang asing". Dengan demikian kasih terhadap Tuhan, juga menuntut diwujudkan dalam kasih kepada orang yang berbeda atau asing.

\section{Implikasi Ajaran Iman Pada Kehidupan Masa Ini}

Manusia diciptakan tidak dapat hidup baik tanpa ketulusan melayani sesama (Francis, 2020). Kehidupan yang terbuka terhadap sesama lebih kuat dari kematian. Sebaliknya, dalam hidup yang terisolasi kematian hadir. Kasih menciptakan ikatan persaudaraan dan memperluas eksistensi. "Para pengasih bergerak keluar". Kehidupan kasih tidak dapat direduksi pada keluarga inti atau kelompok kecil belaka. Keterbukaan pada orang lain, prasyarat untuk membuka jerat kekerdilan yang disebabkan oleh kepentingan diri (Francis, 2020). Dengan demikian, mempromosikan sistem yang menghargai orang asing merupakan perutusan suci masa ini. Sikap ramah terhadap orang asing adalah langkah awal yang perlu dibangun.

Keserakahan menutup kebaikan-kebaikan yang lain kata St. Agustinus. Sebaliknya, kasih membuka kebaikan-kebaikan menurut St. Bonaventura (Francis, 2020). Kasih perlu diutamakan, melampaui resiko dan bahaya (1Kor 13: 1-13). Keterbukaan kasih pada sesama membawa manusia pada kebaikan-kebaikan yang lain. Kasih bukan sekadar kumpulan perbuatan baik, tetapi kasih menggerakkan 
manusia untuk mencari dan mengupayakan yang terbaik bagi sesama. Tidak ada kedewasaan yang dapat dicapai tanpa melewati pencarian kepenuhan diri lewat kasih pada sesama. Implementasi kasih dibutuhkan untuk mentransendensikan keterbatasan-keterbatasan. Rasisme menyerupai virus yang cepat menyebar, dan butuh ditransendensikan dengan kasih. Dewasa ini, banyak orang bahkan diperlakukan sebagai orang asing di negaranya sendiri (Francis, 2020). Para lansia, orang-orang cacat, dan orang-orang miskin hidup tersingkir dalam dunia masa ini. Mereka tidak diajak ikut memiliki dan berpartisipasi aktif dalam tata kehidupan. Kasih dapat mentransendensikan ikatan sempit ini dan melahirkan persahabatan sosial yang lebih luas bagi semua orang.

Globalisasi yang cenderung menyeragamkan, merusak anugerah keunikan setiap manusia (Francis, 2020). Masa depan tiap manusia tidaklah seragam. Karena itu, setiap orang perlu pertama-tama melepaskan rencana dan cita-cita yang bersifat egoistik, untuk dapat meneladan orang Samaria yang baik hati. Ini perlu dilakukan supaya "kasih pada sesama" tidak kehilangan maknanya. Persaudaraan tidak hanya menghargai kebebasan individu tetapi juga memperluas kebebasan dan keadilan bagi sesama. Individualisme tidak dapat membuat dunia lebih bebas, lebih adil, dan lebih bersaudara. Individualisme yang hanya menjumlahkan kepentingan individu, tidak mampu membuat dunia lebih baik. Individualisme adalah virus yang menipu dengan cara mengajarkan bahwa pengejaran ambisi maksimal akan membawa dunia menjadi lebih baik.

Diperlukan kesadaran baru masyarakat akan martabat manusia yang luhur. Setiap manusia punya hak untuk hidup bermartabat dan tumbuh secara menyeluruh. Karena itu, tujuan pembangunan tidak dapat didasarkan oleh kepentingan sempit individu atau kelompok elit, tetapi harus pada kebaikan bersama yang lebih luas. Masalahnya, beberapa orang dibesarkan dalam ekonomi, pendidikan, dll, yang berkecukupan, sedangkan yang lainnya tidak. Inilah yang menyebabkan kaburnya nilai persaudaraan. Karena itu dibutuhkan jempatan yang menghubungkan keduanya. Pengejaran kebaikan umum akan menghubungkan semua orang, mendewasakan manusia akan nilai-nilai moral, dan menghasilkan buah-buah Roh. Pengejaran kebaikan umum mampu mentransendensikan kepentingan diri yang sempit.

Solidaritas lahir dari pertobatan pribadi, komitmen untuk bertanggungjawab terhadap orang lain, dan penyempurnaan diri terus menerus (Francis, 2020). keluarga adalah tempat terbaik untuk menumbuhkan nilai-nilai kasih dan persaudaraan. Solidaritas terekspresi dalam pelayanan, terutama pada yang miskin dan menderita. 
Dalam zaman dengan kecenderungan disintegrasi ini, kita perlu merenungkan kembali makna "soliditas". Soliditas lahir dari kesadaran bahwa kita bertanggungjawab atas kerapuhan sesama dalam rangka membangun masa depan bersama. Karena itu, untuk membaharui dunia butuh kebangkitan kesadaran universal dalam masyarakat global. Keberagaman sama sekali tidak boleh dijadikan dasar untuk menghakimi. Kekayaan keberagaman individu harus dijadikan sarana berkat untuk yang membutuhkan. St. Yohanes Chrysostom menyatakan: "tidak berbagi kekayaan adalah sama dengan merampok hak orang miskin dan mengambil kehidupan mereka......." (Francis, 2020).

Pengembangan dunia tidak boleh berfokus pada kepentingan elite, tetapi harus pada kebaikan untuk semua orang tanpa kecuali. Pengembangan harus termasuk orang-orang yang membutuhkan diseluruh dunia, dengan mengembalikan martabatnya sesuai yang diciptakan Tuhan. Pengembangan dunia harus mampu mengeliminasi ketidak-adilan yang terjadi disemua level: individu, negara, dan regio. Kita perlu mengasipirasi dunia akan pentingnya hal itu. Proposal yang memungkinkan dapat didasarkan pada: etika solidaritas global, dan kerjasama pelayanan untuk masa depan yang dibentuk oleh saling ketergantungan dan tanggungjawab bersama seluruh umat manusia.

Senada dengan pemikiran paus, filsuf moral Australia Peter Singer, menunjukkan bahwa kebebasan mutlak individu pada jaman ini justru membuat kebanyakan orang bingung bagaimana menjalani hidup secara baik (Singer, 1993). Dalam bukunya yang berjudul How Are We To Live, Singer menunjukkan fenomena masa kini bahwa kebanyakan orang yang hidupnya didominasi kepentingan diri, sebenarnya bukan karena mereka dilahirkan egois, tetapi justru karena "pilihan hidup yang terlalu banyak dan membingungkan" (Singer, 1993). Mereka tidak dapat melihat apa yang penting untuk dilakukan. Penghayatan agama yang dangkal membuat mereka tidak dapat melihat hal lain yang berharga untuk dikejar selain kepentingan diri.

\section{Langkah-langkah Mewujudkan Persaudaraan Global}

1. Membangun keterbukaan hati pada seluruh dunia

Topik ini dibahas pada bab 4 ensiklik. Tema ini dibuka dengan ajakan untuk melindungi para migran supaya dapat diterima, dilindungi, dan disatukan di negara yang baru (Francis, 2020). Hal ini dimaksudkan supaya para migran dapat mendapatkan martabatnya kembali dan bebas dari perlakuan diskriminasi. Dibutuhkan 
pengakuan pemerintah global, perencanaan jangka panjang, menengah, dan pendek, untuk mewujudkan hal ini. Paus mengingatkan bahwa para migran punya potensi untuk memperkaya dan membangun kemanusiaan yang menyeluruh (Francis, 2020). Punahnya satu spesies berdampak pada keseluruhan spesies. Karena itu, tiap manusia harus dilindungi karena martabatnya sebagai ciptaan Tuhan. Globalisasi harus menguntungkan semua, terutama pada yang miskin dan tersingkir. Keterbukaan pada orang asing adalah menguntungkan, walau tidak langsung dalam jangka pendek. Sayangnya, beberapa negara hanya terbuka bagi orang-orang yang menguntungkan secara langsung seperti: investor, pakar, dan lain-lain.

Hidup tanpa persaudaraan mirip situasi dagang terus menerus yang melelahkan. Padahal banyak hal kita mendapat secara cuma-cuma dari Tuhan, untuk juga dibagikan secara cuma-cuma pula (Mat 10:8). Nasionalisme yang sempit harus diperluas pada kepentingan persaudaraan diseluruh dunia (Francis, 2020). Tegangan antara globalisasi dan lokalisasi perlu diseimbangkan supaya tidak jatuh pada ekstrim salah satu. Keduanya dapat saling memperkaya lewat mekanisme subsidiaritas. Keterbukaan harus tetap dalam konteks keragaman. Tiap individu harus tetap berakar kuat pada budayanya, namun berkontribusi untuk yang baik bagi semua. Dengan demikian, keberagaman menyehatkan dan memperkaya. Sebaliknya, keseragaman memicu kesombongan dan ambisi. Ini seperti dalam kisah menara Babel.

Tiap individu dipanggil untuk selalu memperluas cakrawala pemikiran dengan cara mencari kebaikan yang lebih luas. Kebaikan dimana tiap individu dihormati martabatnya (Francis, 2020). Narsisme lokal menghasilkan rasa tidak aman dan penolakan terhadap ydi dunia masa iniang berbeda dengan alasan perlindungan diri. Ini penyebab kurangnya solidaritas. Budaya yang tidak mengandung nilai universal bukanlah budaya yang sejati. Dengan demikian, perlu segera menyadari kesempitan hati dan pikiran. Hati yang terbuka dan sehat tidak pernah mencederai identitas. Budaya hidup bersama dalam keberagaman memperkaya dan mempersatukan manusia secara unik. Tidak ada negara/budaya/masyarakat yang dapat memenuhi dirinya sendiri. Butuh yang lain untuk melengkapi keterbatasan masing-masing. Cara pikir yang menganggap orang lain sebagai ancaman, dan oleh karenanya perlu melindungi diri darinya, adalah berbahaya. Cara pikir ini mendidik manusia untuk selalu ketakutan. Keuntungan yang didapat dari isolasi harus dipikirkan ulang. Isolasi tidak mendukung pencapaian kebaikan bersama.

Filsuf Jerman, Max Scheler (1874-1928) menyatakan bahwa nilai-nilai tertinggi pada manusia adalah nilai-nilai spiritual, yang muncul dalam keterbukaan manusia 
pada Yang Misterius, Yang Transenden, Tuhan sendiri (Scheler, 1961). Scheler menegaskan bahwa manusia sebagai individu harus mampu melampaui dirinya sendiri sebagai organisme dan mentransformasi dirinya sendiri. Jadi manusia sebagai mahluk spiritual adalah mahluk yang mampu melampaui dirinya sendiri dalam dunia. Dengan demikian, kesempitan berpikir manusia modern yang egoistik memang perlu dibaharui lewat keterbukaan yang lebih luas.

2. Membangun iklim politik dan bisnis yang lebih baik

Tema ini dibahas pada bab 5 ensiklik. Politik seharusnya melayani kebaikan bersama. Tetapi populisme hanya melayani tujuan sempit elit. Populisme juga cenderung menghilangkan nilai-nilai dan memecah belah masyarakat. Populisme tidak sesuai dengan prinsip-prinsip demokrasi karena hanya ingin menguasai dan melayani mayoritas. Padahal aspirasi keseluruhan masyarakat perlu dilayani. Populisme memanipulasikan penggunaan kata "rakyat" untuk kepentingannya sendiri. Kaum populis hanya mengejar suara jangka pendek dan tidak peduli pada kebaikan yang lebih luas dan jangka panjang. Liberalisme hanya melayani kepentingan ekonomi yang kuat. Karena itu baik populisme maupun liberalisme sulit menyediakan ruang bagi semua orang (Francis, 2020).

Isu terbesar masalah politik masa ini adalah: pengangguran. Pengangguran terkait martabat manusia dalam bekerja. Hidup tidak hanya sekadar butuh makan tetapi juga butuh: pertumbuhan pribadi, relasi, aktualisasi diri, pertukaran talenta, dan sebagainya. Pasar bebas masa ini telah terbukti tidak mampu membendung ketidakadilan dan kekerasan pada yang lemah. Butuh semangat solidaritas untuk menyehatkan pasar bebas. Dibutuhkan energi moral baru yang muncul lewat tujuan kebaikan bersama, supaya simbol-simbol demokrasi tidak menjadi formalitas belaka. Politik perlu dibaharui dengan semangat kasih. Hanya kasih yang bisa menyatukan semua elemen. Hanya kasih yang mampu meredam egoisme dan merubah hati. Egoisme adalah bentuk hawa nafsu yang hanya bisa diatasi dengan bantuan Tuhan. Spiritualitas dan cara hidup menyeluruh, berkembang dalam perhatian kepada sesama.

Pandangan paus ini juga pernah diungkapkan oleh beberapa pemikir terkenal dunia. Filsuf besar Jerman, M. Heidegger, juga menekankan bahwa ciri khas manusia adalah memiliki kemampuan untuk keluar dari dirinya sendiri, untuk berpartisipasi dalam kenyataan yang lebih luas dari dirinya (Sastrapratedja, 2010). Makna hidup diperluas dalam kemampuan manusia untuk keluar dari egonya. Teolog Kristiani terkenal, Thomas Merton, menegaskan bahwa akar cinta adalah "bukan muncul dari 
kehendak untuk mencintai, melainkan iman bahwa seseorang dicintai" (Delio, 2005). Cinta hanya dapat muncul dari seseorang yang telah merasakan dirinya dicintai. Penghayatan religius yang mendalam menghasilkan iman bahwa seseorang dicintai secara mendalam, dan itulah sumber cinta yang memancar keluar dalam hidupnya. Hidup yang dihayati dengan penuh syukur atas kelimpahan kasih yang tak terbatas adalah pondasi cinta. Kungkungan ego justru merupakan jebakan yang menjauhkan manusia dari Sang Sumber Cinta.

Praktik cinta perlu diimplikasikan dalam perpolitikan global. Butuh reformasi PBB supaya tidak hanya bergantung pada beberapa negara yang memiliki hak veto. Kekuasaan tidak boleh mendominasi hukum. Inilah yang menyebabkan prinsip solidaritas mutlak dibutuhkan saat ini. Politik pada masa ini terkesan buruk akibat korupsi, dominasi yang kuat, dll. Padahal dunia juga tidak dapat berfungsi tanpa politik. Karena itu, politik harus dibebaskan dari dominasi ekonomi dan kepentingankepentingan sempit jangka pendek. Fokus pada kebaikan bersama jangka panjang dan kebaikan untuk generasi berikutnya, dapat menyehatkan politik.

Masyarakat global sudah lama menderita, karena itu, perubahan yang fundamental sangatlah dibutuhkan. Politik harus dipulihkan citranya, sebagai panggilan mulia, bentuk perwujudan kasih teringgi dan untuk mencapai kebaikan bersama. Setiap orang harus diarahkan untuk mencapai jati diri dalam kehidupan bermasyarakat, bukan dalam individualisme. Setiap orang harus percaya bahwa kasih kepada sesama yang bersifat sosial mampu membaharui dunia. Pelaksanaan kasih membutuhkan terang iman dan akal budi. Kalau kasih dapat dijadikan spirit politik, maka martabat manusia akan dihargai, solidaritas dan subsidiaritas akan dipraktekkan dengan baik. Dengan demikian, budaya-budaya buruk seperti: marginalisasi, "thrown away", kemarahan, eksploitasi, dll, dapat dieliminasi. Yang lapar, miskin, dan menderita, dapat dibangkitkan.

Politik yang dijiwai kasih selalu bersifat terbuka. Pemimpin harus siap berkorban untuk melayani. Tiap pendapat yang berbeda perlu didengar. Intoleransi tidak dapat diterima karena mencederai martabat manusia. Budaya toleransi dan hidup bersama dalam damai dipromosikan. Pengejaran kenikmatan duniawi yang sempit perlu disembuhkan dengan praktek kasih dalam kehidupan sehari-hari. Politik perlu mempromosikan kasih pada sesama. Bisnis diperbaharui sebagai penggilan mulia untuk memproduksi kesejahteraan bersama, memperbaiki dunia, dan mengembangkan talenta. Bisnis harus menjadi berkat untuk semua orang, bukan hanya para pemilik (Francis, 2020). 
3. Membangun dialog dan persahabatan dalam masyarakat

Tema ini secara khusus dibahas pada bab 6 ensiklik. Dunia saat ini adalah dunia yang tidak memiliki kesabaran berdialog (Francis, 2020). Banyak orang pada masa ini, hidup dalam angan-angan belaka, bukan dalam realitas. Kehidupan semacam ini mendorong mereka bereaksi destruktif. Semangat dialog dengan yang berbeda melemah, sebaliknya monolog antar individu yang seragam menguat. Banjir informasi media sosial yang mencampur opini dengan fakta, membuat orang menjadi keras kepala, sok tahu, dan mudah marah. Karena itu, ini menghambat dialog. Dialog pada masa ini juga sering dimanipulasikan kekuasaan yang punya kepentingan tertentu.

Kurangnya dialog yang terbuka dengan yang berbeda, adalah bukti atas kurangnya perhatian pada kebaikan bersama. Ini juga menunjukkan kecenderungan berfokus pada kepentingan elit. Inilah yang perlu diperbaharui oleh para pahlawan masa depan. Dialog yang otentik muncul dari kemampuan untuk menghargai yang berbeda. Diskusi publik, yang benar-benar terbuka dan tidak memanipulasi informasi, adalah stimulus menuju kebenaran sejati. Diskusi antar disiplin juga sangat diperlukan dewasa ini. Media sosial marus dimanfaatkan untuk mendukung kebaikan hal ini.

Solusi bukanlah relatif, tetapi ada kebenaran yang obyektif. Masa depan masyarakat global terletak pada upaya pencarian kebenaran sejati. Masyarakat perlu dimampukan untuk menyingkapkan kebenaran, yang pada masa ini banyak dimanipulasi dan disesatkan ego. Bahkan pada level konsensus antar negarapun, dapat terjadi manipulasi oleh yang lebih berkuasa atau lebih pandai. Tidak diterapkannya etika membuat hukum rimba berlaku. Dalam masyarakat yang beragam, dialog adalan cara terbaik untuk mentransendensikan situasi konkrit yang dihadapi. Kebenaran sejati, dikenali dalam solusi-solusi yang berfungsi baik bagi masyarakat luas.

Martabat yang berdialog harus dihormati sepenuhnya. Tidak boleh ada paksaan, dominasi, dan manipulasi dalam dialog. Butuh kemampuan untuk dapat menerima hak orang lain untuk berbeda dengan kita. Yang fundamental dan universal dari nilai-nilai moral dapat diterapkan dalam praktek yang berbeda-beda. Dalam kehidupan yang beragam, konfrontasi adalah sebuah seni perjumpaan. Kedamaian sosial membutuhkan kerja keras dan seni yang menyatukan perbedaan yang sulit. Ini mungkin adalah sebuah proses yang lambat, tetapi dialog adalah senjata masa ini. Dialog perlu dilaksanakan dalam semangat kebaikan. Kebaikan adalah salah satu buah roh. Kebaikan membebaskan manusia dari: kekejaman, ketakutan, dan 
kegelisahan. Kebaikan memberi ruang bahwa orang lain juga memiliki hak untuk bahagia. Kebaikan dapat dipraktekkan dalam dialog dengan cara: senyum, kata-kata yang menguatkan, mendengarkan, dll (Francis, 2020).

Pandangan Paus tentang pentingnya membangun keterbukaan lewat dialog yang setara, senada dengan pendapat filsuf moral post modernisme, Jurgen Habermas. Menurut Habermas, norma moral yang universal tidak berasal dari kesadaran individu masing2, melainkan dari apa yang dapat disepakati bersama (Suseno, 2004). Kesepakatan itu harus dicapai lewat pembicaraan bersama yang terbuka bagi semua yang bersangkutan dan bebas dari paksaan. Pembicaraan semacam ini disebut "diskursus". Diskursus bukan tentang keragaman nilai-nilai atau pandangan tentang "hidup mana yang baik", melainkan tentang masalah keadilan, karena yang perlu disepakati adalah bagaimana kita wajib memperlakukan orang lain, termasuk yang dari komunitas lain (Suseno, 2004).

4. Tahapan untuk membaharui perjumpaan pada sesama

Ini adalah pokok bahasan bab 7 ensiklik. Bumi yang terluka ini butuh tahapan perdamaian (Francis, 2020). Setiap hari kita semua berubah. Penderitaan dan konflik yang kita hadapi sehari-hari mengubah kita. Setiap manusia butuh berubah menuju kesempurnaan hidupnya. Karena itu, hal-hal yang disembunyikan dari masyarakat perlu dibuka, supaya masyarakat dapat ikut berproses. Masyarakat berhak tahu apa yang sedang terjadi. Kebenaran tidak terpisahkan dri keadilan dan belas kasih. Kebenaran tidak mengarah balas dendam, melainkan rekonsiliasi dan pengampunan. Tahapan menuju perdamaian harus melibatkan seluruh masyarakat tanpa kecuali.

Masyarakat yang baru harus didasarkan pada pelayanan, bukan dominasi. Tiap orang harus merasakan berada dalam rumahnya sendiri, dalam keluarga sendiri. Konflik bisa saja terjadi tetapi tetap dalam konteks keluarga. Tiap orang perlu ambil bagian dalam membentuk sejarah baru dunia. Ini butuh komitmen dan kerja keras bersama dalam jangka panjang. Teutama bagi yang diberi tanggungjawab lebih besar untuk memulihkan martabat manusia. Kita harus mampu merasakan kehidupan orang miskin dan tersingkirkan. Tanpa keadilan sosial yang sejati, segalanya mudah meledak. Pengampunan dan rekonsiliasi, yang menjadi tema sentral ajaran Kristiani, harus diwujudkan dalam masyarakat. Inilah tugas perutusan iman. Perutusan untuk mengatasi: korupsi, kekerasan, dominasi, dan segala yang mengancam martabat manusia. Cinta sejati membantu mereka yang berjuang mencapai martabatnya.

Langkah awal yang perlu dilakukan adalah membebaskan diri dari: kemarahan, dendam, dan kebencian (Francis, 2020). Memperjuangkan keadilan tidaklah mudah. 
Ini sama saja dengan perjuangan mengalahkan kejahatan dengan kebaikan. Ketika konflik masa lalu tidak diselesaikan dengan baik, maka dapat meletus sewaktu-waktu. Butuh proses dan diskusi yang jujur untuk menyelesaikannya. Orang yang mengalami perlakuan tidak adil dan penderitaan yang diakibatkannya, tidak mudah memaafkan. Mereka butuh proses dan waktu. Semangat instrospeksi dan malu terhadap kesalahan diri sendiri, sangat perlu dibangun. Sejarah tidak boleh dilupakan, tetapi dapat dibaharui maknanya dari hari ke hari. Sejarah mengajarkan hidup dan apa yang pernah terjadi kepada setiap generasi.

Mengampuni tidak berarti melupakan begitu saja. Mengampuni adalah nilai warisan Allah. Pengampun sejati tidak pernah melupakan, supaya tidak jatuh dalam hal yang sama dikemudian hari. Sikap pengampun memampukan memperjuangkan keadilan tanpa jatuh dalam lingkaran balas dendam. Ketidakadilan dapat muncul kembali karena dilupakan. Semua korban dari kedua belah pihak yang pernah berkonflik harus dihargai semestinya. Pembaharuan hati dalam menghadapi sesama akan membawa perubahan mendasar berupa kelembutan dan kerendahan hati, pada politik, budaya, agama, dan bahasa.

Dua hal ekstrim yang perlu ditolak, yaitu: perang dan hukuman mati (Francis, 2020). Perang adalah ancaman yang akan terus ada. Selalu ada nafsu yang berupaya mencari solusi lewat perang. perang menghancurkan persaudaraan dan lingkungan hidup, dan penyebab ketidak-adilan. Setiap perang membuat dunia lebih buruk dari sebelumnya. Ancaman terbesar masa ini adalah besarnya senjata pemusnah yang ada didunia, berupa senjata nuklir, biologi, dll. Biaya persenjataan sebaiknya dialihkan untuk orang miskin.

Kitab Suci Perjanjian Baru mengajarkan bahwa manusia tidak memiliki hak untuk menghakimi sesamanya. Karena itu, Gereja sejak dulu menolak hukuman mati. Kekejaman dan ketakutan, bukanlah bagian dari upaya menyembuhkan penjahat dan mengitegrasikannya dalam masyarakat. Penolakan akan hukuman mati harus termasuk pemusnahan yang dilakukan negara atau rezim diktaktor untuk menghabisi yang dianggap musuh mereka. Hukuman mati, baik legal maupun ilegal harus ditolak. Yang membunuh juga kehilangan martabatnya. Iman kristiani menolak kekerasan dalam bentuk apapun.

Pandangan paus ini selaras dengan pandangan teolog Erich Zenger yang menyatakan bahwa Allah dalam pandangan monoteisme seharusnya merupakan Allah bagi semua orang, yang tidak meminta korban, sebaliknya justru bersedia menjadi korban (Sunarko, 2016). Agama monoteistik tidak mengajarkan kekerasan. 
Hal ini juga diperkuat pendapat Samuel P. Huttington, yang dalam menjawab kritik yang dialamatkan padanya, menyatakan bahwa kekerasan bukan sifat asli agama, melainkan buah instrumentalisasi perasaan-perasaan religius melalui agitasi demi kepentingan politik semata (Sunarko, 2016).

5. Agama-agama bersama melayani persaudaraan di dunia masa ini

Tema ini menjadi pokok bahasan bab terakhir ensikilik (bab 8). Agama-agama, berdasarkan penghormatan pada setiap manusia sebagai ciptaan Allah, dapat berperan dan berkontribusi dalam membangun persaudaraan dan keadilan di dunia masa ini (Francis, 2020). Pengakuan diciptakan oleh satu Allah punya konsekwensi kita dapat hidup bersama secara damai. Akar totalitarianisme modern mengacaukan ini dengan menolak paham penciptaan manusia oleh Allah, sesuai citraNya. Atas nama ideologi, mereka berusaha meniadakan Tuhan dalam kehidupan masyarakat. Akibatnya, masyarakat kehilangan idola, tujuan, dan martabatnya. Ini membuat kesadaran masyarakat makin kabur, dan jauh dari nilai-nilai agama. Masyarakat akhirnya terjebak dalam individualisme dengan filsafat materialistik yang mengagungkan manusia.

Gereja perlu membangunkan lagi energi spiritual untuk memperbaiki masyarakat, tanpa masuk dalam politik yang menjadi domain awam (Francis, 2020). Gereja percaya bahwa Tuhan juga bekerja dalam agama-agama lain. Gereja menunjukkan kepada dunia arti "katolik", dimana dalam pengalaman rahmat dan dosa, mengacu pada keindahan undangan untuk menyatu pada kasih yang universal. Karena itu, Gereja perlu selalu memperjuangkan kebebasan bagi yang minoritas, serta membangun pengertian dan harmoni dengan budaya dan agama-agama yang berbeda. Upaya bersama antar agama-agama menuju perdamaian itu memungkinkan, bahkan para ateis pun dapat ambil bagian bersamanya. Bersama-sama perlu mencari kesempatan berdialog untuk mengatasi kemiskinan dan mengupayakan kebaikan untuk semua orang. Kekerasan antar manusia tidak pernah dibenarkan agama.

Pemujaan agama tidak boleh berbuah kebencian, diskriminasi, dan kekerasan, tetapi harus berbuah penghormatan pada kesucian dan martabat manusia. Kekerasan fundamentalis disebabkan oleh pimpinan agama yang tergesa-gesa mengambil langkah. Perintah perdamaian ada dalam kedalaman tiap ajaran agama. Para pemimpin agama dipanggil untuk menjadi motor dialog dan membangun mediasi perdamaian sejati. Bersama Imam besar Al-Thayeb, Paus menyerukan bahwa agamaagama perlu menjaga untuk tidak menjadi pencetus perang, kebencian, kekerasan, 
dan ekstrimisme, karena pada dasarnya ini bukanlah ajaran agama. Tetapi ini buah manipulasi politik yang menggunakan nama Tuhan untuk menyebarkan ketakutan.

Pendapat paus ini senada dengan yang diungkapkan tokoh nasionalis Islam Indonesia, Achmad Syafii Maarif, bahwa bencana bisa saja terjadi bila pemeluk agama kehilangan nalar, memonopoli kebenaran, dan kemudian menggunakan nama Tuhan untuk menghakimi yang berbeda (Wahid, 2009). Ini adalah bentuk fundamentalisme agama atau ideologi yang bertentangan dengan Islam serta tradisi budaya Indonesia yang seharusnya bersifat santun, toleran dan moderat. Agama sering digunakan sebagai alat politik identitas, untuk menjatuhkan lawan-lawan politik dengan cara kotor dan hasutan kebencian (Wahid, 2009).

\section{KESIMPULAN}

Ensiklik ini menunjukkan akar permasalahan dunia masa ini, yaitu budaya totalitarianisme modern yang menolak paham penciptaan manusia oleh Allah, sesuai citraNya. Akibatnya, masyarakat kehilangan idola, tujuan, dan martabatnya yang sejati. Ini membuat kesadaran masyarakat makin kabur, dan jauh dari nilai-nilai agama. Masyarakat akhirnya terjebak dalam individualisme dengan kecenderungan materialistik yang mengagungkan manusia. Kecenderungan materialistik menjadikan manusia makin egois, tertutup (isolasi), dan berfokus pada kepentingan diri. Kecenderungan negatif ini makin lama makin menguat dipicu globalisasi. Kecenderungan ini bersifat destruktif pada persaudaraan antar manusia, dan alam sekitarnya.

Untuk mengatasi permasalahan ini, Paus berupaya membangunkan lagi energi spiritual persaudaraan kasih antar manusia. Ini dilakukan untuk memperbaiki masyarakat, politik, bisnis, dan semua aspek kehidupan. Semangat baru berupa penghormatan pada martabat manusia, termasuk juga yang berbeda (asing), dan fokus kepada kebaikan bersama yang lebih luas, diharapkan dapat membuka kembali isolasi kesempitan diri dan egoisme masyarakat modern. Semangat yang mampu membawa pembaharuan dunia yang lebih baik dan ramah bagi semua orang. Perikop Injil "orang Samaria yang baik hati" menjadi dasar ajaran proposal ini.

Ensiklik ini menunjukkan kualitas analisa dan kausalitas yang baik, yang menghubungkan antara permasalahan dan proposal solusi. Ensiklik juga searah dengan pendapat pemikir lain yang relevan. Oleh karenanya, ensiklik ini terbukti relevan untuk dijadikan bahan studi, dialog, dan implementasi bersama bagi semua pihak yang berkehendak baik dan punya tanggungjawab terhadap dunia. 


\section{DAFTAR PUSTAKA}

Agger, B. (2004). The Virtual Self: A Contemporary Sociology. Blackwell Publishers.

Bertens, K. (2001). Filsafat Barat Kontemporer. Gramedia.

Delio, I. (2005). The Humility of God. St. Anthony Messenger.

Francis, P. (2020). Life After Pandemic. Vatican Press.

Harari, Y. N. (2011). Sapiens. Pustaka Alfabet.

Harari, Y. N. (2015). Homo Deus. Pustaka Alfabet.

Harari, Y. N. (2018). 21 Adab untuk Abad ke 21. CV. Global Indo Kreatif.

Maqin, K. (Ed.). (2020). Wabah, Sains, Dan Politik. Antimoni.

Nichols, T. (2017). The Death of Expertise. Oxford University Press.

Sastrapratedja, M. (2010). Filsafat Manusia I. Pusat Kajian Filsafat dan Pancasila.

Scheler, M. (1961). Man's Place in Nature. The Noonday Press.

Setiawan, H. (2014). Manusia Utuh. Kanisius.

Singer, P. (1993). How Are We to Live. Mandarin Book.

Sinjders, A. (20014). Manusia: Paradoks dan Seruan. Kanisius.

SJ., I. L. M. U., \& Pr., M. P. (Eds.). (2015). Setelah Setengah Abad, Kemana Kita Melangkah? Kanisius.

Society, V. E. \& W. (2000). Globalization and Its Victims (M. Amaladoss (Ed.)). Vidyajyoti Education \& Welfare Society.

Sunarko, A. (2016). Teologi Kontekstual. Obor.

Suseno, F. M. (2004). Etika Abad Kedua Puluh. Kanisius.

Wahid, K. H. A. (2009). Ilusi Negara Islam. PT. Desantara Utama Media.

Zizek, S. (2020). Pandemic, Covid 19 Shakes The World. OR Books. 